\title{
Dificultăți și provocări în traducerea literaturii române în limba polonă. Studiu de caz: romanul Soldații. Poveste din Ferentari al lui Adrian Schiop
}

\author{
Olga Bartosiewicz-Nikolaev \\ Universitatea Jagiellonă din Cracovia \\ olga.bartosiewicz@uj.edu.pl
}

Studiul de față își propune prezentarea celor mai mari provocări și dificultăți întâlnite pe parcursul traducerii în limba polonă a romanului Soldații. Povestea din Ferentari al lui Adrian Schiop, examinând cele mai reprezentative strategii de traducere și de adaptare culturală folosite în textul-țintă. Articolul aduce în prim plan importanța contextului sociocultural al romanului (condiția socială a manelelor și a manelismului, puterea imaginară a cartierului Ferentari) și subliniază rolul traducătorului ca mediator cultural și rolul traducerii ca formă a transferului cultural.

Cuvinte-cheie: traducere literară - literatura română în Polonia - strategii de traducere - mediere culturală - manele și manelism

Romanul Soldații. Poveste din Ferentari al lui Adrian Schiop constituie una dintre cele mai discutate apariții din ultimul timp în România. În primul rând datorită tematicii controversate pe care o abordează (relația homosexuală între personajul principal și prietenul lui rom din cel mai sărac cartier din București, Ferentari, descrisă pe fondul realităților sociale, economice și culturale ale acestei zone), în al doilea rând - datorită vocabularului extrem de inventiv, argotic și foarte des vulgar, care predomină în narațiune.

În calitate de traducătoare a romanului lui Schiop în limba polonă, îmi propun prin acest articol să evidențiez cele mai mari dificultăți și provocări pe care leam întâlnit pe parcursul traducerii. Dincolo de asta, aș mai dori să semnalez strategiile pe care le-am folosit pentru ca cititorul polonez să înțeleagă contextele sociale și culturale ale romanului analizat. Până acum [februarie 2021], cartea a fost tradusă numai în limba polonă; a fost publicată la editura Universitas de la Cracovia, într-o serie intitulată „Rumunia dzisiaj” [România astăzi], al cărei scop este acela de a promova literatura română contemporană în Polonia.

Studiul de față a rezultat din practica traducerii, găsindu-și bazele teoretice în școala lui Gideon Toury (1995), care depășește granițele paradigmei filologice și se orientează spre observarea interferențelor socioculturale ce se produc în 
timpul actului de traducere. Deși Toury elaborează „un set de norme specifice unui comportament traductologic" (Jeanrenaud 2006: 287), el propune o atitudine descriptivă și nu prescriptivă, permițând „,modificarea, în traducere, a relațiilor textuale cu textul-sursă, prin remanierea, adaptarea lor în conformitate cu repertoriul uzual în cultura-țintă" (Jeanrenaud 2006: 287) și deplasând centrul de greutate dinspre respectarea echivalenței față de textul original spre strategia acceptabilității în cadrul contextului-țintă.

\section{Context cultural și social}

Receptarea romanului lui Schiop, considerat de la bun început o carte controversată, a depășit mai multe tabuuri existente în societatea românească. Unul dintre ele fiind manelele - genul muzical considerat de o mare parte a societății românești ca întruchiparea prostului gust și a kitschului. Potrivit sociologului Vintilă Mihăilescu, acestea întrupează cinci păcate capitale în societate, dintre care cele mai semnificative ar fi păcatul național - „[Manelele] reprezintă o subminare a europenismului modern al națiunii române prin (re) căderea în Orient" (Mihăilescu 2014: 190) și păcatul rasial - fiindcă sunt cântate preponderent de romi, societatea vede în ele expresia directă a valorilor rome, vehiculul pervers al „t,iganizării României” (Mihăilescu 2014: 191). Acestea reprezintă deci un fenomen social important, deoarece nu se limitează doar la muzică, ci stau la baza unui întreg imaginar care funcționează în conștiința colectivă a societății. Și cartea lui Schiop ${ }^{1}$ își propune să tematizeze problema manelelor și să exploreze autenticitatea artistică a acestora, recurgând la estetica microrealistă specifică literaturii douămiiste din primul val. În acest roman autoficțional apar atât acest univers textual al manelelor, cât și cel social al manelismului.

Introducerea naratorului care este un soi de alter-ego al autorului real (jurnalistul Adi se înscrie la un doctorat pe tema manelelor și pentru a se documenta se mută în Ferentari) care trăiește în lumea prostituatelor, homosexualilor, hoților, romilor și vagabonzilor, reprezintă un concept al prozei angajate, care constituie un fel de răspuns la marginalizarea socială a grupurilor considerate a fi o amenințare la adresa ordinii publice. Puterea subversivă a manelelor organizează nu numai câmpul tematic al textului (șmecherie, sărăcie, lume interlopă, pușcărie), dar intră și în structura narațiunii - prin paratexte, adică motto-urile anumitor capitole, provenite din versurile diferitelor manele, dând astfel lecturii o anumită interpretare. Așadar, întregul roman este precedat de un citat provenit din cântecul Mi-ai spus să te aştept al lui Babi Minune, iar

1 Trebuie totuși subliniat, că Soldații nu reprezintă primul roman al lui Schiop în care acesta abordează problema condiționării sociale a muzicii, vezi de ex. cartea lui de debut pe bune/pe invers [Polirom 2004], unde apar discuții asupra muzicii anilor 90. Mai mult decât atât, el și-a construit lucrarea de doctorat pe tema condițiilor sociale complicate ale manelelor, intitulată Șmecherie și lume rea. Universul social al manelelor [Cartier 2017]. 
fiecare dintre cele două părți ale romanului se deschide cu un motto „manelist” respectiv din Iau bani de la cămătari al lui Denis și din Fă Doamne fereastra ușă al formației Albatros.

În plus, în corpul textului putem găsi foarte des citate din mai multe cântece, ceea ce creează o rețea specifică de referințe la lumea cunoscută numai celor care ascultă manele. Aceasta reprezintă o mare provocare pentru traducător, care trebuie să fie vigilent la metaforele, sintaxa și strategiile retorice folosite în narațiune - ca de exemplu în fragmentul următor: „Alberto zicea (...) șapte numere îți dau"(Schiop 2013: 133). Partea indicată cu caractere italice se referă la piesa sexistă a lui Romeo Fantastic, Taci și urcă-te pe mine, unde aceste „numere” sunt sinonime cu acte sexuale. Am tradus această frază în limba polonă cu „Wykręcę ci siedem numerków", făcând o contaminare semantică prin alăturarea a două elemente: „numerek” [un număr mic] poate însemna în limbajul colocvial „un act sexual”, iar expresia „,wykręcić komuś numer” înseamnă „, a face cuiva o surpriză neplăcută". Datorită acestui procedeu este salvată toată rețeaua semantică cititorul polonez are de a face nu numai cu o aluzie sexuală ascunsă sub un fel de amenințare glumeață, ci și cu potențialul metaforic al acestei expresii. Așadar, rămâne păstrată intenționalitatea textului-sursă.

Și tocmai această mediere culturală a reprezentat pentru mine cea mai mare provocare în timpul traducerii. De fapt nu vulgarismele, multiplele colocvialisme sau folosirea preponderentă a discursului indirect liber (pe care nu-1 raționalizez urmăresc fidel eterogenitatea originalului, unde uneori este imposibil de disociat instanțele enunțiative), ci întregul câmp lexical legat de imaginarul culturii maneliste și al Ferentariului mi-au creat cele mai multe dificultăți.

\section{Adaptarea culturală a textului-țintă}

Este evident că titlul operei joacă un rol foarte important în receptarea acesteia, putându-se chiar argumenta că sintetizează întregul ei mesaj. Pentru un cititor avizat din spațiul românesc titlul romanului lui Schiop este sugestiv (cartierul Ferentari are o poziție bine definită în topografia Bucureștiului). Pentru un cititor din alt spațiu cultural, titlul este opac - de aceea am hotărât să explic locul cartierului Ferentari în imaginarul colectiv al bucureștenilor și al românilor în Postfață. Aceasta joacă de altfel un rol foarte important, fiindcă acolo am explicat cititorului polonez contextul acesta destul de ermetic al lumii prezentate în roman. Am explicat și originea latină a numelui „Ferentari”: latinescul „ferentarius” denumește un soldat din infanteria ușoară a legiunilor romane - Schiop se joacă atunci de la bun început cu dubla semnificație a cuvântului - soldații, adică protagoniștii romanului care se luptă cu viața și rămân fideli idealurilor lor, și în același timp sunt legați semantic de cartierul din care provin.

Identitatea culturală a romanului este conturată prin concepte care definesc anumite roluri sociale ale căror echivalente funcționează în polonă într-un context semantic mult mai sărac. Așadar, unul dintre cuvintele care apar cel mai des în text, în jurul cărora a fost construită narațiunea despre Ferentari, este „șmecher" 
- adică cineva care, potrivit definițiilor din DEX „știe să iasă din încurcături”, ,"nu poate fi păcălit”, ,,se pricepe la viclenii” și „,caută să se remarce ca om de spirit prin manifestări ostentative menite să epateze pe cei din jur"; de fapt, conceptul poate avea, în funcție de context, sensuri pozitive sau peiorative. Atunci, cuvântul acesta îl traduc în majoritatea cazurilor ca „cwaniak”, „cwaniaczek” [formă de diminutiv], "dzielnicowy cwaniaczek” (în ultimul caz folosesc adjectivul „dzielnicowy" [de cartier] pentru a sublinia relația șmecherului cu cartierul Ferentari); în mai multe locuri în care contextul o permite, folosesc și termenul argotic „,kozak” care transmite mai precis bogăția sensului din versiunea originală, fiindcă acest cuvânt descrie o persoană care este curajoasă și a făcut ceva despre care ceilalți cred că este dificil, greu sau imposibil.

Un alt cuvânt care apare adesea în textul românesc, ",boschetar”, îl traduc în majoritatea cazurilor ca „,żul” sau „,menel” - în română acest termen poate însemna bețiv și pierzător, în sens peiorativ „,boschetarul” este privit cu dispreț, dar și cu un soi de milă, iar în argoul urban termenul este folosit ca termen vulgar pentru o persoană homosexuală. În ultimul sens, însă, acest cuvânt nu apare în proza lui Schiop, el folosește alți termeni pentru a descrie homosexualitatea. Mă opresc atunci la un sens care în limba polonă indică într-un mod ofensator o persoană săracă, un bețiv și, la fel ca în original, își păstrează conotațiile existențiale și sociale legate de un exclus, un cineva din afară, un străin.

Termenul „manele” îl introduc în traducere în grafia sa originală. În limba română, forma de mai sus a acestui substantiv indică pluralul feminin nearticulat, dar am decis să folosesc acest cuvânt în poloneză în genul neutru singular, astfel încât termenul să nu fie confundat cu substantivul autohton „manele” (feminin plural), care este folosit pentru a descrie mulțimea obiectelor personale. Așadar, cuvântul „manele” este folosit în traducere cu un înţeles asemănător termenilor „pop” sau „rock” și se referă explicit la genul muzical.

În mai multe cazuri folosesc și jargonul de închisoare, dar, urmărind strategia textului-sursă, nu explic sensul acestor cuvinte cititorului, fiindcă acesta trebuie să simtă că are de a face cu un limbaj special, trebuie creat un efect de înstrăinare lingvistică.

$\mathrm{Nu}$ am tradus expresiile din limba rromani (pentru ca lumea prezentată în carte să nu-și piardă credibilitatea și să-și păstreze culoarea locală), dar am adăugat la unele dintre ele un echivalent polonez: „Borcănică, horcăia la telefon, nu mai pot fără voi, haptekar” (Schiop 2013: 227) - „Uliśku, rzęził do telefonu, nie wytrzymuję już bez was, haptekar do chuja" (Schiop 2018: 217). Elementul adăugat este un vulgarism, folosit pentru a clarifica replica grosolană a lui Alberto. Astfel, avem aici un cuvânt împrumutat din rromani plus o explicație în limba-țintă.

Cât despre numele proprii de locuri și străzi din București, le-am tradus, pe cât posibil, în limba polonă, pentru a face topografia capitalei românești mai accesibilă și mai inteligibilă cititorului polonez (mai ales că unele dintre acestea posedă deja varianta lor poloneză, constituită prin tradiția istorică). Însă, în Postfață am oferit o cheie fonetică simplificată pentru numele pe care le-am lăsat în original și pentru numele și prenumele personajelor - toate fără excepție rămase în forma lor originală, fiind considerate, prin tradiție, intraductibile și constituind astfel, 
cum a arătat Michel Ballard, ,"grad zero al reprezentărilor culturale"(Ballard 1998: 199). În schimb, am încercat să traduc majoritatea poreclelor, deoarece acestea sunt utilizate de obicei cu încărcătură simbolică (foarte des și comică) - traducerea lor garantează deci păstrarea conotațiilor semantice din versiunea originală.

Doar în cazul unui personaj, vărul lui Alberto, am schimbat complet porecla, fiindcă în versiunea originală îl cheamă Borcan, iar în polonă „borcanul” e un cuvânt „încărcat” semantic. Cu expresia „borcane de la Varșovia” sunt descrise persoanele care au venit în capitală din provincie pentru muncă și pleacă în fiecare weekend acasă la țară, întorcându-se cu borcane cu mâncare de la mama. I-am explicat autorului această situație, iar el a propus să-l numim atunci pe vărul lui Alberto în traducerea poloneză „Ulises”. Ceea ce este interesant, pentru că alegerea lui Schiop nu este o alegere aleatorie, ci atinge ordinea non-ficțională a romanului. Așadar, textul-țintă oferă posibilitatea unor noi interpretări, pentru că numele Ulises are o valoare semantică și culturală puternică.

Bineînțeles, de mai multe ori am recurs și la note de subsol ca să explic noțiunile inexistente în spațiul cultural polonez, cum ar fi: „lăutari", ,manele"; numele diferitelor mâncăruri și băuturi: „mici”, „țuică”; unele nume proprii: mărcile berilor (Ursus, Timișoreana, Ciuc), coniacul Alexandrion, titlurile ziarelor (România Liberă, Adevărul), postul de televiziune Taraf, compania RENEL, referințe topografice (Hanul Drumețului, Poartă Albă, Vama Veche), unele personaje autentice (Florin Salam, Gigi Becali, Nuțu Cămătaru, Emi Pian, Ion Dolănescu).

In ceea ce privește alegerile artistice: dintr-o serie de mijloace lingvistice echivalente cu mesajul din limba-sursă am selectat mijloacele adecvate și ca registru, și ca stil, recurgând foarte des la limbajul folosit în Polonia de către tinerii care se identifică cu anumite cauze sociale sau segmente media, precum participanții la un reality show ca Warsaw Shore (unde stilul de viață este marcat prin consumarea abuzivă de alcool, petreceri, apologia corpului și a sexualității) - acest limbaj, marcat prin mai multe greșeli gramaticale și sintactice, mi s-a părut cel mai adecvat și cel mai asemănător cu stilul de la Ferentari prezent la Schiop și, evident, neexistent nicăieri în Polonia. Echivalența trebuia deci găsită prin alte mijloace. Încercând să traduc cât mai bine stilul narațiunii, am folosit uneori tehnica traducerii prin compensare, compensând astfel un element de pierdere sau de omisiune: de exemplu, am recurs la modificarea topicii, care dă sentimentul limbajului vorbit, acolo unde am simțit că ar fi mai natural în limba polonă.

Traducând versurile manelelor, am recurs la stilistica pieselor disco-polo, așa numita muzică populară urbană, care s-a dezvoltat și s-a răspândit foarte repede, ca și manelele, în anii ‘90, cu melodii simple, versuri adesea indecente, rime banale, multe colocvialisme și afectivitate exagerată.

\section{Receptarea textului în Polonia}

Proza lui Schiop a provocat în România reacții similare debutului Dorotei Masłowska sau al lui Michał Witkowski în Polonia; în orice caz, din punct de vedere tematic, lingvistic și stilistic, scrierea autorului român se apropie de opera 
literară a autorilor menționați mai sus. O astfel de literatură se dezvoltă în afara canonului corectitudinii formale a dicționarului, comentând cu îndrăzneală și fără compromis realitatea socială și cea care se încadrează în tendințele mișcării LGBTQ+.

Traducerea s-a bucurat de o bună primire din partea publicului și a criticii literare (a obținut premiul de debut al celei mai prestigioase reviste de literatură în traducere, „,Literatura na świecie” [Literatura în lume]), deci vreau să cred că acest proces de mediere culturală s-a terminat cu succes, și că acest context social ermetic al romanului nu a învelit mesajul universal al cărții, care nu reprezintă doar un portret cvasi-etnografic al cartierului bucureștean marginalizat, exclus, ci constituie o poveste despre singurătate, neînțelegere și relații interpersonale dificile. Tocmai pentru că știm foarte bine că literatura poate transmite aceste emoții indiferent de limbă și experiență culturală.

\section{Bibliografie :}

Ballard, Michel (1998). La traduction du nom propre comme négociation, in: Palimpsestes, 11, pp. 199-223.

Jeanrenaud, Magda (2006). Universaliile traducerii. Studii de traductologie, Iași: Polirom.

Mihăilescu, Vintilă (2014). De ce urâm țiganii. Eseu despre partea blestemată, manele și manelism, in : Condiția romă și schimbarea discursului, [ed. Vintilă Mihăilescu, Petre Matei], Iași: Polirom, pp. 189-223.

Schiop, Adrian (2013). Soldații. Poveste din Ferentari, Iași: Polirom.

Schiop, Adrian (2018). Żotnierze. Opowieść z Ferentari, trad. Olga Bartosiewicz, Kraków: Universitas.

Toury, Gideon (1995). Descriptive Translation Studies and beyond, AmsterdamPhiladelphia: John Benjamins.

Dicționare ale limbii române, dexonline.ro (15/04/2020). 


\section{Difficulties and Challenges in Translating Romanian Literature into Polish. Case Study: The Novel "Soldiers. Story from Ferentari" by Adrian Schiop}

The main purpose of this paper is to present the challenges and difficulties which appeared during the process of translation from Romanian into Polish of the novel Soldații. Poveste din Ferentari [Soldiers. Story from Ferentari] written in 2013 by Adrian Schiop. The article discusses mostly some practical solutions of translation problems and also some strategies used by the translator. It finds its theoretical basis in the beginnings of the cultural turn in translation studies - when the act of translation became a complex process of intercultural negotiation and stopped being considered as a simple interlingual relationship of equivalences. Thus, special attention is given to the cultural and social context of the translated novel (the phenomenon of the controversial musical genre "manele") and to the strategies of cultural adaptation - the translator is perceived here as a cultural mediator.

Key words: literary translation - the practice of translation - Romanian literature in Poland - cultural mediation - "manele" phenomenon 
